\title{
Effect of Feeding Lactating Ewes with Moringa oleifera Leaf Extract on Milk Yield, Milk Composition and Preweaning Performance of Ewe/Lamb Pair
}

\author{
Gabriel Olvera-Aguirre ${ }^{1}$ D, Miriam Marleny Mendoza-Taco ${ }^{1}$, Darwin Nicolas Arcos-Álvarez ${ }^{2}$, \\ Angel Trinidad Piñeiro-Vázquez ${ }^{2}$, Victor Manuel Moo-Huchin ${ }^{3}$ D , Jorge Rodolfo Canul-Solís ${ }^{4}$, \\ Luis Castillo-Sánchez ${ }^{4}\left(\mathbb{D}\right.$, Marco Antonio Ramírez-Bautista ${ }^{5}$, Einar Vargas-Bello-Pérez ${ }^{6, *(D)}$ and \\ Alfonso Juventino Chay-Canul 1,*(D) \\ 1 División Académica de Ciencias Agropecuarias, Universidad Juárez Autónoma de Tabasco, km 25. \\ Carretera Villahermosa-Teapa, R/A La Huasteca., Colonia Centro Tabasco 86280, Mexico; \\ 13030027@itesa.edu.mx (G.O.-A.); marmirlen@hotmail.com (M.M.M.-T.) \\ 2 Tecnológico Nacional de México, Instituto Tecnológico de Conkal, Conkal, Yucatán 97345, Mexico; \\ darwin.arcos@itconkal.edu.mx (D.N.A.-Á.); angel.pineiro@itconkal.edu.mx (A.T.P.-V.) \\ 3 Tecnológico Nacional de México, Instituto Tecnológico de Mérida, km 5 Mérida-Progreso, Mérida, \\ Yucatán 97120, Mexico; vmmoo@yahoo.com \\ 4 Tecnológico Nacional de México, Instituto Tecnológico de Tizimín, Tizimín, Yucatán 97000, Mexico; \\ jcanul31@gmail.com (J.R.C.-S.); luis.castillo@ittizimin.edu.mx (L.C.-S.) \\ 5 Tecnológico Nacional de México, Instituto Tecnológico de Chiná, Chiná, Campeche 24520, Mexico; \\ tonorb75@hotmail.com \\ 6 Department of Veterinary and Animal Sciences, Faculty of Health and Medical Sciences, University of \\ Copenhagen, Grønnegårdsvej 3, DK-1870 Frederiksberg C, Denmark \\ * Correspondence: evargasb@sund.ku.dk (E.V.-B.-P.); aljuch@hotmail.com (A.J.C.-C.)
}

Received: 15 May 2020; Accepted: 24 June 2020; Published: 29 June 2020

Simple Summary: The use of plant extracts as supplemental additives in ruminant diets shows beneficial effects. This study evaluated the effects of different doses of Moringa oleifera leaf extract (MOE) on milk production and milk composition in ewes and on preweaning performance of their lambs. At different doses, MOE supplementation did not affect overall productive traits in ewes and lambs and did not have negative effects on milk production and milk quality.

\begin{abstract}
The objective this study was to evaluate the effect of different doses of Moringa oleifera leaf extract (MOE) on milk production and milk composition in ewes and on preweaning performance of their lambs. Twenty-four lactating ewes were housed individually with their lambs and assigned to four groups in a completely randomized design. The treatments included a basal diet without MOE (MOE0) or a basal diet supplemented with either $20 \mathrm{~mL}$ MOE per ewe per day (MOE20), $40 \mathrm{~mL}$ MOE per ewe per day (MOE40) or $60 \mathrm{~mL}$ MOE per ewe per day (MOE60). Over 45 days, milk production was recorded weekly and individual milk samples were collected for chemical analysis. Milk yield, fat-corrected milk and daily yields were similar among the four treatments. The supply of MOE did not affect ewe weaning efficiency and average daily gain or litter weaning weight of the lambs. Overall, the results from this study showed that dietary supplementation of hydroalcoholic extracts of Moringa oleifera leaves at doses of 20, 40 or $60 \mathrm{~mL} / \mathrm{ewes} / \mathrm{d}$ in lactating ewes does not have negative effects on milk yield, milk composition or lamb performance.
\end{abstract}

Keywords: performance; lactation; herbal extract; milk composition; milk yield; performance; supplementation in lactating ewes 


\section{Introduction}

In recent years, the use of agricultural byproducts, herbal plants and/or their extracts as feed additives in ruminant production systems has increased due to their relative low cost, their potential to replace synthetic products and consumers' high demand for organic animal products [1-4]. Agroindustrial byproducts consist of considerable amounts of bioactive components, such as polyphenols (tannins or flavonoids), and these compounds exert antimicrobial activities to improve immune status and reduce stress [3,4]. Medicinal plants are used in animal nutrition to improve performance, feed efficiency, nutrient utilization, overall animal health and quality of livestock products, which are effects related to their abilities to increase oxidative stability [4-6].

During lactation, adequate energy levels in the diets of ewes improves body condition score, body weight, milk yields and, consequently, weight gain of their lambs [6,7]. In this context, some authors reported that supplementation of lactating ewes' diets with foliage and meal obtained from leaf and other plant components improved milk yield, milk fat and milk fatty acid profiles [8,9]. Some authors reported that due to their oxidative stability, phenolic compounds, tannins, saponins and flavonoids could be used to improve the functional properties of milk, meat and derived products of small ruminants $[4,8,10,11]$.

Recently, interest focused on Moringa oleifera (MO), a highly versatile and sustainable tree mostly cultivated in the tropics and subtropics [12]. MO is very useful as a feed supplement for animals $[10,13,14]$ and is an important source of protein (up to $35 \%$ of dry matter, DM) and fibre (up to $28 \%$ DM) [15-17]. In addition to its nutritional properties, MO leaves are sources of bioactive compounds, such as antioxidants, vitamins, phenolic acids and flavonoids, and are available at relatively low cost in resource-limited areas, making it a promising source of bioactive compounds for functional food production and nutraceutical product development [12,14].

Several authors $[1,16,18,19]$ reported that dietary supplementation with MO leaves or extracts increased dry matter intake (DMI), total solids in milk, milk nonfat solids, milk fat, daily milk yield (DMY) and energy-corrected milk yield (ECM) in goats. Moreover, Moyo et al. [20] concluded that supplementation with $\mathrm{MO}$ leaves in goat diets protected animals against diseases induced by oxidative stress, as shown in liver enzymes. Until now, no study determined whether supplementing ewes with MO extracts impacted both the dam and the lamb preweaning performances. We hypothesized that supplementation of lactating ewe diets with MOE would be a useful strategy to improve ewe performance and milk composition, with positive consequences on suckling lamb performance. Therefore, the objective of this study was to evaluate the effects of supplementing lactating ewes with increasing doses of MO leaf extracts on milk yield and milk composition, and on the preweaning performance of ewe/lamb pair. The choice to use extracts rather than plant parts from MO was due to the extracts being concentrated solutions of secondary plant compounds, and their delivery and supply is constant all year round.

\section{Materials and Methods}

\subsection{Management of Animals and Experimental Design}

The animals were treated in accordance with the guidelines and regulations for animal experimentation of the División Académica de Ciencias Agropecuarias, Universidad Juárez Autónoma de Tabasco (ID project PFI: UJAT-DACA-2015-IA-02). The study was carried out at the "Rancho San Francisco", located at $21^{\circ} 14^{\prime} 48^{\prime \prime} \mathrm{N}$ and $89^{\circ} 02^{\prime} 35^{\prime \prime} \mathrm{W}$ longitude, $5 \mathrm{~m}$ above sea level (masl), in Dzidzantun municipality (Yucatán, Mexico). The average temperature is $26^{\circ} \mathrm{C}$, with $9.8 \mathrm{~mm}$ of rainfall during the experimental months (between November and December) and extremes of relative humidity between $66 \%$ and $89 \%$ [21,22]. Twenty-four clinically healthy crossbreed (Pelibuey $\times$ Katahdin) ewes that had recently lambed (2 days) were randomly assigned to four groups of six animals each. Ewes were $2-3$ years old with a mean body weight (BW) of $35.7 \pm 5.02 \mathrm{~kg}$ and a body condition score (BCS) 
of $2.07 \pm 0.18$ [23] with a single lambing. The number of animals for each treatment was based on a similar study dealing with dietary interventions [24].

After lambing, each ewe and their offspring were allocated together in individual pens $(2 \times 3 \mathrm{~m})$ and managed under a feedlot system for 45 days. The ewes had free access to feed and water. For the lambs, water was always available, but they did not have access to the ewes' feeders. At the beginning of the study, ewes were dewormed with Closantel $5 \%{ }^{\circledR}$ (Wyeth LLC, Madison, NJ, USA) at a dosage of $10 \mathrm{mg} / \mathrm{kg}$ of body weight.

The basal diet consisted of a concentrate (offered at 8:00 am) based on ground corn, soybean meal, sugarcane molasses and minerals and fresh chopped Taiwan grass (P. purpureum; offered at 18:00 h), using only stems in order to reduce the nutritional variation throughout the experimental phase, in a proportion of 80:20 (concentrate:forage) ratio. The basal diet had an estimated metabolizable energy of $11.5 \mathrm{MJ} / \mathrm{kg}$ DM and $15 \%$ crude protein [25] (Table 1) to meet the energy requirements and to avoid ewe weight loss, thereby maintaining the body condition score. This strategy was performed to prevent body fat mobilization and possible confounding effects on milk composition. The objective was to maintain constant BW and BCS of ewes throughout the study, as described previously [26]. Throughout the experiment, the diet was offered ad libitum, with feeding levels designed to ensure a daily refusal margin of $10 \%$. The dry matter intake (DMI) was determined by the difference between the amount of diet offered and the amount refused. Animals had free access to water. The basal diet was supplemented with Moringa oleifera leaves extract (MOE) provided at doses (per ewe daily) of either $0 \mathrm{~mL}$ (control), $20 \mathrm{~mL}$ (ME20), $40 \mathrm{~mL}$ (ME40) or $60 \mathrm{~mL}$ (ME60). The MOE was supplied daily in the concentrate. In order to avoid feed sorting, treatments were manually mixed with $200 \mathrm{~g}$ of concentrate and, after animals consumed it, the rest of the meal was provided. The diets were formulated to meet the theoretical requirements for dairy ewes with a mean BW of $45 \mathrm{~kg}$ and a mean milk yield of $1.74 \mathrm{~kg} / \mathrm{d}$, with milk total protein and fat contents of $4.5 \%$ and $7.0 \%$, respectively, according to the Agricultural and Food Research Council [25] guidelines.

Table 1. Chemical composition ( $\mathrm{g} / \mathrm{kg}$ of dry matter) of the concentrate and forage offered to lactating ewes.

\begin{tabular}{ccc}
\hline Parameter & Concentrate & Forage \\
\hline Dry matter & 900 & 283 \\
Crude protein & 150 & 31 \\
Neutral detergent fibre & 438 & 693 \\
Acid detergent fiber & 160 & 470 \\
Organic matter & 963 & 953 \\
Ether extract & 43 & 19.2 \\
Metabolizable energy (MJ/kg DM) * & 11.5 & 7.6 \\
\hline
\end{tabular}

${ }^{*}$ Estimated from [22].

The BW of each ewe was recorded weekly. The amount of feed offered to each ewe was adjusted weekly according to BW [23]. The data collected also included initial (IBW, kg) and final (FBW, kg) body weights from each ewe. Calculated traits included daily preweaning weight gain of lambs (ADG, $\mathrm{kg}$ ), average daily body weight change of ewes (BWC, $\mathrm{kg}$ ) during lactation, which was estimated as the difference between FBW and IBW divided by 45 days, and litter weaning weight (LWW, kg), which was was obtained as the sum of weight of weaned lambs by ewe. Ewe weaning efficiency (EE) was calculated as $\mathrm{LWW} / \mathrm{FBW} \times 100$ [23].

\subsection{Milk Yield and Composition}

Milk yield (MY, kg) and lamb body weights (LBW, $\mathrm{kg}$ ) were measured every week (on Saturdays) from the first week of the experiment until day 45 (6 weeks). The lambs were separated from their dam at 19:00 h. After $12 \mathrm{~h}$ of separation, the ewes were hand-milked after an intramuscular injection of 3 international units of oxytocin (Pisa, Mexico). Before milking, the teats were cleaned with an 
iodine solution and dried with paper towels. Daily milk yield (DMY, $\mathrm{kg}$ ) of ewes during the week of measurement was calculated by the milk obtained over the $12 \mathrm{~h}$ period, which was multiplied by 2 to reflect the DMY [26].

For milk composition analysis, samples from each ewe $(100 \mathrm{~mL})$ were obtained every week. Analyses for fat, protein and lactose were performed in duplicate using an automatic milk analyzer (Lactoscan LS-60, Milkotronic Ltd., Nova Zagora, Bulgaria). The equipment was calibrated for fat by the Gerber method and for protein by total nitrogen determination according to the Dumas method using a LECO CNS-2000 series 3740 analyzer (LECO Corp. St. Joseph, MI, USA). Additionally, fat-corrected milk yield (FCM) to $6 \%$ was calculated according to the formula [27]:

$$
\mathrm{FCMY}=(0.28+0.12 \mathrm{~F}) \times \mathrm{MY}
$$

where $\mathrm{F}=$ fat percentage. Energy-corrected milk yield (ECMY, kg) was calculated according to the formula [28]

$$
\mathrm{ECMY}=(0.071 \times \mathrm{F}+0.043 \times \mathrm{P}+0.2224) \times \mathrm{MY}
$$

where $\mathrm{P}$ is protein percentage.

\subsection{Moringa oleifera Leaf Extract}

The MOE was prepared at the beginning of the experiment and stored at $20^{\circ} \mathrm{C}$ in a dark room (to avoid oxidation) for daily use. The MO leaves were randomly collected from young and mature plants. Leaves were cut ( 1 to $2 \mathrm{~cm}$ long) and dried at $40^{\circ} \mathrm{C}$ for $72 \mathrm{~h}$ in a forced convection oven. The dried leaves were ground with a mill $(0.5-1 \mathrm{~mm})$ and the resulting powder was immediately processed. The leaf powder was subjected to extraction with a 50\% aqueous ethanol in a ratio of 1:20 for $2 \mathrm{~h}$ under continuous stirring $(120 \mathrm{rpm})$ at $25^{\circ} \mathrm{C}$. The resulting extract was centrifuged at $1500 \mathrm{rpm}$ for $10 \mathrm{~min}$ at $25^{\circ} \mathrm{C}$. The supernatant was collected and the pellet was subjected to additional extraction using the same procedure as described above. Supernatants from both extractions were pooled and finally stored.

\subsection{Antioxidant Content}

The contents of MOE total saponins, hydrolyzable tannins, condensed tannins, total phenolic compounds and total flavonoids were determined by spectrophotometry. Furthermore, in vitro antioxidant activity was determined by 2,2-diphenyl-1-picrylhydrazyl (DPPH) and 2,2'-azinobis(3-ethylbenzothiazoline-6-sulfonic acid) (ABTS) assays. In both methods, the DPPH and ABTS radicals were reduced by hydrogen donation of the antioxidant.

\subsection{Total Saponins}

Total saponins content was determined as described by Ncube et al. [29]. Samples containing $250 \mu \mathrm{L}$ of extract and $250 \mu \mathrm{L}$ of vanillin reagent ( $8 \%$, in ethanol) were mixed and $2.5 \mathrm{~mL}$ of sulfuric acid was added $(72 \%, v / v)$. The solution was mixed in a vortex and placed in a water bath at $60^{\circ} \mathrm{C}$ for $10 \mathrm{~min}$. The test tubes were allowed to cool down for $4 \mathrm{~min}$ and absorbance was measured at $544 \mathrm{~nm}$ using a UV-Vis spectrophotometer Agilent Technologies Cary 60 (Santa Clara, CA, USA). Total saponins were expressed as milligrams of diosgenin equivalents per $100 \mathrm{~mL}$ of plant extract $(\mathrm{mg} \mathrm{DE} / 100 \mathrm{~mL})$. The calibration curve of diosgenin showed a linearity range from 80 to $800 \mathrm{ppm}\left(\mathrm{r}^{2}>0.99\right)$.

\subsection{Condensed Tannins}

Condensed tannins were determined based on the vanillin- $\mathrm{HCl}$ method described by Selcuk and Erkan [30]. A $0.5 \mathrm{~mL}$ extract sample was mixed with $3 \mathrm{~mL}$ of vanillin reagent $(4 \%, w / v$, in methanol) and $1.5 \mathrm{~mL}$ of concentrated $\mathrm{HCl}$ was added. The mixture were stirred in a vortex, the solution was kept in the dark for $15 \mathrm{~min}$ at $25^{\circ} \mathrm{C}$ and the absorbance was read at $500 \mathrm{~nm}$ using a UV-Vis spectrophotometer 
Agilent Technologies Cary 60 (Santa Clara, CA, USA). Total condensed tannins were expressed as milligrams of catechin equivalents per $100 \mathrm{~mL}$ of plant extract $(\mathrm{mg} \mathrm{CE} / 100 \mathrm{~mL})$. The calibration curve of catechin showed a linearity range from 5 to $300 \mathrm{ppm}\left(\mathrm{r}^{2}>0.99\right)$.

\subsection{Hydrolysable Tannins}

Hydrolyzable tannins were determined based on the method described by Çam and Hiş1 [31]. A $1 \mathrm{~mL}$ extract sample was mixed with $5 \mathrm{~mL}$ of $\mathrm{KIO}_{3}(2.5 \%, w / v$, in water) (previously exposed for $7 \mathrm{~min}$ at $30^{\circ} \mathrm{C}$ ). The mixture was exposed to $30^{\circ} \mathrm{C}$ for $2 \mathrm{~min}$ and the absorbance was measured at $550 \mathrm{~nm}$ using a UV-Vis spectrophotometer Agilent Technologies Cary 60 (Santa Clara, CA, USA). Hydrolyzable tannins were expressed as milligrams of tannic acid equivalents per $100 \mathrm{~mL}$ of plant extract $(\mathrm{mg}$ TAE$/ 100 \mathrm{~mL}$ ). The calibration curve of tannic acid showed a linearity range from 500 to $5000 \mathrm{ppm}\left(\mathrm{r}^{2}>0.99\right)$.

\subsection{Total Phenolic Compounds}

The amount of total phenolic compounds was determined based on the methods described by Moo-Huchin et al. [32]. A total of $50 \mu \mathrm{L}$ of extract was mixed and equilibrated for 5 min with $3 \mathrm{~mL}$ of distilled $\mathrm{H}_{2} \mathrm{O}$ and $250 \mu \mathrm{L}$ of Folin-Ciocalteu reagent $(1 \mathrm{~N})$. After equilibrium, $750 \mu \mathrm{L}$ of $\mathrm{NaCO}_{3}(20 \%$, $v / v, \mathrm{H}_{2} \mathrm{O}$ ) was added, followed by $950 \mu \mathrm{L}$ of distilled $\mathrm{H}_{2} \mathrm{O}$. The solution was stirred and incubated for $30 \mathrm{~min}$ at $25^{\circ} \mathrm{C}$ and the absorbance was read at $765 \mathrm{~nm}$ using a UV-Vis spectrophotometer Agilent Technologies Cary 60 (Santa Clara, CA, USA). Total phenolic compounds were expressed as milligrams of gallic acid equivalents per $100 \mathrm{~mL}$ of plant extract (mg GAE/100 mL). The calibration curve of gallic acid showed a linearity range from 100 to $1000 \mathrm{ppm}\left(\mathrm{r}^{2}>0.99\right)$.

\subsection{Total Flavonoid Contents}

Flavonoid contents were determined based on the methods described by Moo-Huchin et al. [32], where $1 \mathrm{~mL}$ of extract was mixed and equilibrated with $4 \mathrm{~mL}$ of distilled $\mathrm{H}_{2} \mathrm{O}$ and $300 \mu \mathrm{L} 5 \% \mathrm{NaNO}_{2}$ for $5 \mathrm{~min}$. After equilibrium, $300 \mu \mathrm{L}$ of $10 \% \mathrm{AlCl}_{3}$ (methanol solution) was added. The mixture was kept for $1 \mathrm{~min}$ and then $2 \mathrm{~mL}$ of $1 \mathrm{M} \mathrm{NaOH}$ was added. The last volume was made up to $10 \mathrm{~mL}$ with distilled $\mathrm{H}_{2} \mathrm{O}$. The mixture absorbance was determined at $415 \mathrm{~nm}$ using a UV-Vis spectrophotometer Agilent Technologies Cary 60 (Santa Clara, CA, USA). The concentration of total flavonoids was calculated using a standard curve of quercetin $0-1000 \mathrm{ppm}\left(\mathrm{r}^{2}>0.99\right)$ and expressed as $\mathrm{mg}$ of quercetin equivalents $(\mathrm{QE}) / 100 \mathrm{~mL}$ of plant extract.

\subsection{Antioxidant Activity}

The DPPH (2,2-diphenyl-1-picrylhydrazyl) assay was conducted according to Moo-Huchin et al. [32], where $100 \mu \mathrm{L}$ extract was added to $3.9 \mathrm{~mL}$ of freshly prepared DPPH solution $\left(6 \times 10^{-5} \mathrm{M}\right.$ in methanol). The mixtures were shaken and kept in the dark at $25^{\circ} \mathrm{C}$ for $30 \mathrm{~min}$. The mixture absorbance was determined at $515 \mathrm{~nm}$. A calibration curve was prepared using Trolox as the standard and the results were expressed as $\mathrm{mM}$ Trolox equivalents $/ 100 \mathrm{~mL}$ of extract.

The ABTS (2,2-Azinobis-3-ethylbenzotiazoline-6-sulphonic acid) assay was conducted according to Moo-Huchin et al. [32]. The ABTS radical was formed via the reaction between $7 \mathrm{mM} \mathrm{ABTS}{ }^{+}$solution and $140 \mathrm{mM}$ potassium persulfate solution. The solutions were incubated in the dark at $25^{\circ} \mathrm{C}$ for $18 \mathrm{~h}$. The ABTS-activated radical was diluted with ethanol to an absorbance of $0.70 \pm 0.02$ at $734 \mathrm{~nm}$. Then, $30 \mu \mathrm{L}$ extract was transferred to a test tube with $2970 \mu \mathrm{L}$ of the ABTS radical. The absorbance was determined at $734 \mathrm{~nm}$ after $30 \mathrm{~min}$. Trolox was used as a standard and the results were expressed as $\mathrm{mM}$ Trolox equivalents/100 $\mathrm{mL}$ of extract. 


\subsection{Statistical Analyses}

Data on ewe performance traits (total milk yield TMY, DMY, BWC, LWW and EE) and lamb performance traits (BW and ADG) were analyzed using a completely randomized design by analysis of variance considering treatments as fixed effects and the ewe or lamb as random effects. Tukey's test was performed when a significant treatment effect $(p<0.05)$ was detected. Linear $(L)$ and quadratic $(Q)$ effects of treatments were tested for the response variables. All statistical analyses were performed using the Statistical Analysis System software [33].

Repeated measures of ewe milk production and milk components were analyzed using the MIXED procedure with a mixed linear model that included the fixed effect of sampling day, treatment, two-way interaction of treatment $\times$ sampling day and the random effect of ewe. Repeated measures using the same animal were modeled assuming a compound symmetry (CS) covariance structure.

The linear expression of the model was

$$
Y_{i j k l m}=\mu+E w e_{i}+\operatorname{Trat}_{j}+D m_{k}+\operatorname{Trat} * D m_{l}+\varepsilon_{i j k l m}
$$

where $Y_{i j k l m}$ represents TMY, DMY, ECM $\ldots, \mu$ is the overall mean, $E w e_{i}$ is the random effect of the $i$-th ewe, $T r a t_{j}$ is the fixed effect of the $j$-th treatment, $D m_{k}$ is the fixed effect of the $k$-th Day of measurement, Treat $* D m_{l}$ is the fixed effect of the $l$-th treatment $\times$ day measurement interaction and $\varepsilon_{i j k l m}$ is the residual random effect.

\section{Results}

At the end of the experiment (last three weeks), one animal from ME40 treatment was removed from the experiment due to illness associated with locomotion problems. These data were not included in the analysis.

\subsection{Moringa oleifera Extracts}

The yield obtained by successive hydroalcoholic extractions under orbital agitation was $1.34 \pm$ $0.009 \%$. The MOE phytochemical assays showed high concentrations of bioactive compounds (Table 2) in the form of antioxidants (tannins, phenols and flavonoids), with a total phenolic content of $140.41 \mathrm{mg}$ of galic acid equivalent (GAE). This resulted in a great capacity to capture free radicals, as demonstrated by the amount of Trolox eq $100 \mathrm{~mL}^{-1}$ of the extract supported by the DPPH and ABTS tests (Table 2).

Table 2. Condensed tannins, hydrolyzable tannins, total phenolic compounds, total flavonoid contents and antioxidant activity (DPPH and ABTS) of Moringa oleifera leaf hydroalcoholic extract.

\begin{tabular}{cc}
\hline Compound & Amount (Mean \pm SE) \\
\hline Total saponins $(\mathrm{mg} \mathrm{DE} / 100 \mathrm{~mL})$ & $21.39 \pm 1.40$ \\
Condensed tannins $(\mathrm{mg} \mathrm{CE} / 100 \mathrm{~mL})$ & $7.77 \pm 0.13$ \\
Hydrolysable tannins $(\mathrm{mg} \mathrm{TAE} / 100 \mathrm{~mL})$ & $182.55 \pm 11.03$ \\
Total phenols $(\mathrm{mg} \mathrm{GAE} / 100 \mathrm{~mL})$ & $140.41 \pm 3.40$ \\
Total flavonoid $(\mathrm{mg} \mathrm{QE} / 100 \mathrm{~mL})$ & $3.72 \pm 0.19$ \\
DPPH $(\mathrm{mM}$ trolox equivalent $/ 100 \mathrm{~mL})$ & $32.63 \pm 3.74$ \\
ABTS $(\mathrm{mM}$ trolox equivalent $/ 100 \mathrm{~mL})$ & $200.13 \pm 8.84$ \\
\hline
\end{tabular}

Data are represented as mean \pm SE of three measurements. DE: Diosgenin equivalent; CE: cathechin equivalent; TAE: tannic acid equivalent; GAE: gallic acid equivalent; QE: quercetin equivalent.

\subsection{Ewe and Lamb Performance}

No significant effects between treatments were observed regarding TMY, DMY, milk components or daily yield (Table 3). Daily milk yield, fat-corrected milk 6\% (FCM6), milk fat and milk protein varied over time (Figure 1). The DMI $\left(\mathrm{kg} \mathrm{d}^{-1}\right)$ was higher $(p=0.02)$ for MOE40 compared with MOE60, however, this did not differ from MOE0 and MOE20. Also, DMI $\left(\mathrm{g} \mathrm{kg}^{0.75-1} \mathrm{~d}^{-1}\right)$ was greater $(p<0.001)$ 
for MOE40 compared with MOE20 and MOE60, but did not differ from MOE0 (Table 4). In addition, BWC, LWW and EE were similar among treatments $(p>0.05)$. Likewise, there was no difference in ADG $(p>0.05)$ or weaning weight of lambs at 45 days between treatments (Table 4$)$.

Table 3. Milk yield and composition in Pelibuey $\times$ Katahdin ewes supplemented with Moringa oleifera leaf extract.

\begin{tabular}{|c|c|c|c|c|c|c|}
\hline \multirow[t]{2}{*}{ Variable } & \multicolumn{4}{|c|}{$\begin{array}{l}\text { Daily Moringa oleifera Extract } \\
\text { Supplementation }(\mathrm{mL})\end{array}$} & \multirow[t]{2}{*}{ SE } & \multirow[t]{2}{*}{$p$-Value } \\
\hline & $\mathbf{0}$ & 20 & 40 & 60 & & \\
\hline Total milk yield $(\mathrm{kg})$ & 48.7 & 49.2 & 57.1 & 53.4 & 5.10 & 0.66 \\
\hline Daily milk yield $(\mathrm{kg})$ & 1.15 & 1.13 & 1.28 & 1.23 & 0.12 & 0.87 \\
\hline \multicolumn{7}{|l|}{ Milk composition } \\
\hline Fat $(\%)$ & 6.27 & 6.11 & 6.09 & 6.01 & 0.08 & 0.13 \\
\hline Protein $(\%)$ & 4.24 & 4.33 & 4.21 & 4.52 & 0.09 & 0.12 \\
\hline \multicolumn{7}{|l|}{ Daily yields } \\
\hline Fat-corrected milk (kg/d) & 0.79 & 0.85 & 0.89 & 0.95 & 0.08 & 0.59 \\
\hline Energy-corrected milk (kg/d) & 0.74 & 0.77 & 0.83 & 0.87 & 0.07 & 0.68 \\
\hline Fat yield $(\mathrm{kg} / \mathrm{d})$ & 0.04 & 0.04 & 0.05 & 0.05 & 0.004 & 0.43 \\
\hline Protein yield $(\mathrm{kg} / \mathrm{d})$ & 0.05 & 0.05 & 0.05 & 0.05 & 0.004 & 0.79 \\
\hline
\end{tabular}

Fat-corrected milk and energy-corrected milk were calculated according to [24,25]. SE: Standard error.

Table 4. Preweaning ewe and lamb performance traits in Pelibuey $\times$ Katahdin ewes supplemented with Moringa oleifera leaf extracts.

\begin{tabular}{|c|c|c|c|c|c|c|}
\hline \multirow[t]{2}{*}{ Variable } & \multicolumn{4}{|c|}{$\begin{array}{l}\text { Daily Moringa oleifera Extract } \\
\text { Supplementation }(\mathrm{mL})\end{array}$} & \multirow[t]{2}{*}{ SE } & \multirow[t]{2}{*}{$p$-Value } \\
\hline & 0 & 20 & 40 & 60 & & \\
\hline Dry matter intake (kg/d) & $2.08^{a, b}$ & $1.98^{a, b}$ & $2.37^{a}$ & $1.89^{b}$ & 0.09 & 0.02 \\
\hline Dry matter intake $(\mathrm{g} / \mathrm{kg} 0.75 / \mathrm{d})$ & $137^{\mathrm{a}, \mathrm{b}}$ & $125^{b, c}$ & $143^{a}$ & $121^{\mathrm{c}}$ & 3.08 & $<0.001$ \\
\hline Initial body weight (kg) & 34.6 & 37.3 & 38.1 & 36.4 & 2.20 & 0.72 \\
\hline Final body weight (kg) & 40.7 & 42.3 & 46.9 & 42.2 & 2.41 & 0.38 \\
\hline Body weight change $(\mathrm{kg} / \mathrm{d})$ & 0.137 & 0.111 & 0.195 & 0.129 & 0.02 & 0.28 \\
\hline Litter weaning weight (kg) & 14.2 & 13.7 & 15.1 & 13.7 & 0.57 & 0.38 \\
\hline Ewe efficiency $(\%)$ & 35.2 & 32.7 & 32.2 & 33.1 & 1.64 & 0.63 \\
\hline Birth weight $(\mathrm{kg})$ & 3.66 & 3.52 & 3.82 & 3.30 & 0.25 & 0.55 \\
\hline $\begin{array}{l}\text { Average daily preweaning } \\
\text { gain in lambs }(\mathrm{kg} / \mathrm{d})\end{array}$ & 0.23 & 0.22 & 0.25 & 0.23 & 0.01 & 0.30 \\
\hline
\end{tabular}

Body weight change: Change in ewe body weight per day during lactation calculated as (final body weight - initial body weight)/45 days. Ewe efficiency was calculated as (litter weaning weight/final body weight) $\times 100$. Means in the same row with different superscripts $(a, b, c)$ are different $(p<0.05)$. SE: Standard error. 

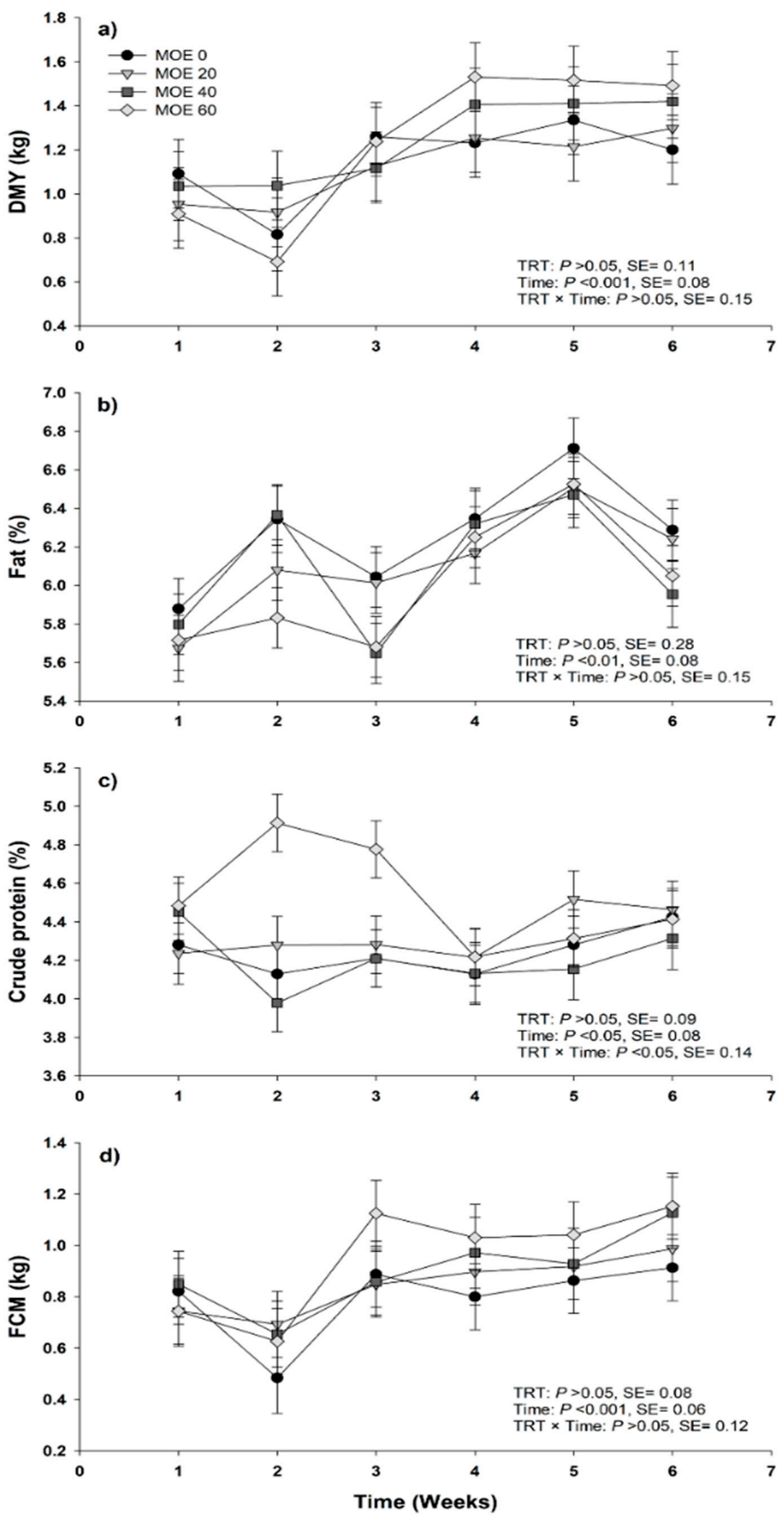

Figure 1. Daily milk yield (DMY) (a), milk fat (b), milk protein (c) and fat-corrected milk (FCM) at $6 \%$ (d) from animals supplemented with Moringa oleifera leaves extract provided at doses (per ewe daily) of either $0 \mathrm{~mL}$ (control), $20 \mathrm{~mL}$ (ME20), $40 \mathrm{~mL}$ (ME40) or $60 \mathrm{~mL}$ (ME60). Bars denote standard error of the means. 


\section{Discussion}

\subsection{Moringa oleifera Extracts}

In this study, the obtained yield for MO hydroalcoholic extract was $1.34 \%$, which was lower than yields reported by Vongsak et al. (7.9\%) [34] and Saleem et al. (40.5\%) [35] in aqueous solutions with methanol and hydroalcoholic extracts (70\% ethanol-water). However, the contents of bioactive compounds and antioxidant activity found in the present study were comparable to previous work $[20,35,36]$ using aqueous solutions with methanol and acetone MO leaf (fresh and dry) extracts. The most important components of MO leaf extracts are phenols, tannins and flavonoids, such as quercetin, catechin, tannic acid and gallic acid, which exhibit biological and pharmaceutical activities (e.g., antibiotic, anti-inflammatory, antioxidative). Some authors [20] reported that the MO acetone and water extracts presented inhibition percentages in ABTS and DPPH of 95.27\% and 72.89\% and 98.24\% and $83.56 \%$, respectively, compared to butylhydroxytoluene (98\% inhibition) at $1 \mathrm{mg} \mathrm{mL}^{-1}$, with total phenols of 120.33 and 40.27 and total flavonoids of 295.01 and $45.1 \mathrm{mg} \mathrm{g}^{-1}$. These high antioxidant activity levels attributed to polyphenolic compounds suggest that they could be used as supplements to prevent oxidative stress-related diseases in animals.

\subsection{Milk Production}

In underfed ruminants or during periods of high nutrient demand, such as gestation and lactation periods, if nutritional requirements are not fulfilled, oxidative stress is generated, consequently producing disease states, low production performance, higher mortality rates and poor product quality [37]. With regard to production performance, some authors [13,18,19] reported an increase in milk production, total solids in milk and nonfatty solids when supplementing lactating ruminants with $\mathrm{MO}$ as a strategy for supplying dietary antioxidants. Also, when supplying MO leaf meals to lactating goats [18], increases in DMI, MY, energy-corrected milk, fat, protein and lactose were observed. However, when replacing alfalfa with MO leaves in lactating Nadji ewes, [13] DMY was not affected during the adaptation period, but it did increase between the third and sixth weeks of lactation. In the Nadji ewes study, no significant differences between treatments were observed in milk composition, but numerical increases in milk fat (17\%), lactose (16\%) and energy output (35\%) were observed. The authors concluded that dietary inclusion of $\mathrm{MO}$ in Najdi ewes improved milk yield and milk quality. On the other hand, [14] supplemented Jersey cows with 30 and $60 \mathrm{~g}$ of MO meal per animal per day exhibited no differences in DMY, protein or lactose, but fat increased at a dose of $60 \mathrm{~g} \mathrm{~d}^{-1}$ compared to the control group.

In the present study, MO hydroalcoholic extracts were used as supplements in lactating sheep. Although the use of alcohol as a solvent may cause detrimental effects in animals, several authors pointed out that alcohol consumption in sheep is common when providing fermented feeds, which reach concentrations of 10 to $50 \mathrm{~g} \mathrm{~kg}^{-1}$ [38,39]. They also pointed out that in ruminants, alcohol is naturally metabolized by fungi and bacteria in the rumen, and these animals can easily metabolize 150 to $180 \mathrm{mg} / \mathrm{kg}$ BW due to the presence of alcohol dehydrogenase in their body [38]. Alcohol doses between 0.2 to $1 \mathrm{~g} \mathrm{BW} \mathrm{EtOH} \mathrm{d}{ }^{-1}$ were used in sheep [39]. When adding $5 \%$ ethanol or acetic acid to the diets of dairy cows, Daniel et al. [39] found differences in DMI, milk fat and milk protein, however, DMY showed an improved response when supplemented with 5\% ethanol. Under the conditions of the present study, MOE supplementation in lactating ewes had no effect on milk yield and milk composition. One explanation for the lack of MOE effects on milk production traits may be the number of animals used in the study or the mild concentrations of treatments. In either case, the objective of this study was accomplished, as the different MOE doses were intended not to have negative effects on milk production traits. 


\subsection{Ewe Performance Traits}

In this study, no differences in animal performance were observed between treatments. However, some authors reported that supplementation with leaf extracts of different plants with powerful antioxidant activity in moderate doses had positive effects on ADG [3], milk yield, oxidative stability in products such as milk and meat and attenuation of diseases related to oxidative stress, such as mastitis or heat stress $[13,40]$. Under the conditions of this study, MOE did not cause significant changes in ewe and lamb preweaning performance. However, it is important to note that some other variables, such as apparent nutrient digestibility, ruminal fermentation parameters and blood metabolic profiles, may have been affected but were not analyzed. Further research efforts should analyze the effects of MOE on rumen function and blood metabolites.

Several authors reported decreases in DMI when lactating sheep were supplemented with high amounts of polyphenols (especially condensed tannins). However, goats were reported to possess greater ability to tolerate and digest these compounds compared to sheep [4]. Likewise, Kholif et al. [1] supplemented lactating Nubian goats with 10, 20 and $40 \mathrm{~mL} /$ day of MOE obtained from fresh leaves in aqueous solution and reported a linear improvement of DMI, however, the supplementation had no effect on the performance of goats (IBW, FBW or BWC). It should be noted that Kholif et al. [1] used aqueous MOE obtained from fresh leaves and that the extract was stored at $4{ }^{\circ} \mathrm{C}$, whereas in the present study, MO leaves were dried at $40^{\circ} \mathrm{C}$ for $72 \mathrm{~h}$ and the hydroalcoholic extract was stored at $20^{\circ} \mathrm{C}$. Also, a study carried out by Adegun and Aye [41] in West African Dwarf Rams sheep reported that supplementation of Pannicum maximum with MO meal had no effect on the IBW, FBW and BWC, but DMI decreased as MO supplementation levels increased. On the other hand, Kekana et al. [14] microsupplemented Jersey cows with 0,30 and $60 \mathrm{~g}$ of MO meal per animal per day and did not observe differences in DMI and BWC. In the present study, the animals' basal diets allowed them to meet their nutritional requirements, which was reflected in a positive performance throughout the experiment. In addition, the ewes gained $(p<0.05) \mathrm{BW}$ and BCS, indicating that over the experiment they were in a positive energy balance.

In this study, even though overall performance and milk production traits were not changed, some changes may have occurred in the rumen microflora, as reported by Dong et al. [2]. These authors supplemented lactating Holstein cows with different levels of MO foliage and reported that milk yield and energy-corrected milk were similar between treatments. They also reported an increase in the abundance of the Methanosphaera genus and Methanosphaera sp. ISO3-F5, which was induced by secondary metabolites of $\mathrm{MO}$ in the diet, suggesting that $\mathrm{MO}$ supplementation not only improves energy density in milk (fat content), but could also be used as a potential additive to reduce methane emissions.

\subsection{Lamb Performance Traits}

It was reported that preweaning is a very important stage in all production systems focused on meat production [26]. In this study, supplementation of MOE in lactating ewes did not negatively affect growth performance and weaning weight (LWW) in suckling lambs. This is very important for lamb performance, since ewe milk is the only food source during the early life of a lamb [26]. Preweaning growth essentially depends on ingested energy, but this was not evaluated in this study. However, if maternal milk was provided to lambs in low amounts of poor nutritional quality, the lamb growth rates and their survival would have deteriorated during the preweaning period [26].

No significant effects on milk energy intake in lambs $(4.25 \pm 1.53 \mathrm{MJ} / \mathrm{d}$, data not presented $)$ were observed. Although little is known regarding energy intake from sheep receiving MOE, one study reported that metabolizable energy intake in ewe's increases with MO leaves supplementation [13]. The energy partition and utilization from sheep receiving plant parts or extracts from MO remains unknown.

The preweaning performance traits found in this study were higher (220 to $250 \mathrm{~g} / \mathrm{d}$ ) then those reported by Chay-Canul et al. [26], who fed animals in similar conditions and reported ADG of lambs 
from 150 to $160 \mathrm{~g} / \mathrm{d}$. On the other hand, Guzman et al. [42] and McGrath et al. [40] reported that antioxidant supplementation may help prevent negative effects of oxidative stress associated with growth in young ruminants, thereby reducing the incidence of morbidity and mortality and ultimately improving their performance. Also, Guzman et al. [42] supplemented lactating goats with concentrates rich in orange byproducts as a strategy to supply antioxidants and found no differences between the treatments in terms of BW and LWW in their suckling kids.

Another strategy to improve lamb performance is to increase energy density in dam diets. In this regard, Titi and Al-Fataftah [43] supplemented lactating Awassi ewes with 3\% and 5\% soybean or sunflower oil and evaluated the effects on performance and on their suckling lambs. They reported no improvements in initial or final ewe BW or changes in these levels, and milk intake of lambs decreased in comparison to the control diet (no fat supplemented). Average daily gains (286-314 $\mathrm{g} \mathrm{d}^{-1}$ ) were not affected by dietary supplementation with oils and the milk conversion ratio ( $\mathrm{kg}$ milk/kg ADG) only varied with sunflower oil at 5\% DM. Gallardo et al. [44] evaluated the effect of supplementing linseed oil (3\%) and natural or synthetic vitamin E in lactating Churra ewes with their lambs and observed that oil supplementation did not affect ADG, BW or LWW of suckling lambs. Under tropical and subtropical conditions, perhaps the best feeding strategy is to use extracts and byproducts from native plants [45]. In this context, even though the use of oils was reported to increase dietary energy density and improve lamb performance [44], the use of plant extracts may be an appropriate choice as they are available and easy to mix into diets.

When using plant extracts, it is important to note that animal responses may vary depending on their bioactive compound contents. In the present study, despite the high proportion of phenolic acids $(140.41 \pm 3.40)$ expressed in GAE $100 \mathrm{~mL}^{-1}$ of MOE and condensed and hydrolyzed tannins $(7.77$ $\pm 0.13,182.55 \pm 11.03$ ), expressed as $\mathrm{mg} \mathrm{CE}$ or TAE $100 \mathrm{~mL}^{-1}$ of MOE, no increases in milk yield or composition or performance of lambs or their mothers were observed.

Further studies should consider studying the effects of MOE on oxidative stress, blood parameters and quality of animal products. Also, higher doses of $\mathrm{MOE}$ and increased numbers of animals per treatment should be included.

\section{Conclusions}

Overall, the results from this study showed that dietary supplementation of hydroalcoholic extracts of Moringa oleifera leaves at doses of 40 or $60 \mathrm{~mL} /$ ewes/d in lactating ewes did not have negative effects on milk yield, milk composition or lamb performance. For greater scientific reach, further studies should consider the use of Moringa oleifera focusing on rumen function, blood metabolites and fatty acid profiles of animal products, such as meat, milk and dairy products.

Author Contributions: Conceptualization, G.O.-A. and A.J.C.-C.; methodology, G.O.-A., M.M.M.-T., D.N.A.-Á, A.J.C.-C., V.M.M.-H. and E.V.B.-P.; software, J.R.C.-S., L.C.-S. and M.A.R.-B.; validation G.O.-A., A.J.C.-C., V.M.M.-H. and E.V.B.-P.; formal analysis, G.O.A., M.M.M.-T., D.N.A.-Á. and V.M.M.-H.; investigation, G.O.-A., M.M.M.-T., J.R.C.-S., L.C.-S., M.A.R.-B., A.J.C.-C. and A.T.P.-V.; resources, A.J.C.-C., A.T.P.-V. and V.M.M.-H.; data curation, A.J.C.-C.; writing-original draft preparation, G.O.-A., A.J.C.-C. and E.V.B.-P.; writing-review and editing, G.O.-A., A.J.C.-C., and E.V.-B.-P.; visualization, J.R.C.-S., L.C.-S. and M.A.R.-B.; supervision, G.O.-A., A.J.C.-C., A.T.P.-V. and V.M.M.-H.; project administration, A.J.C.-C.; funding acquisition, A.J.C.-C. and A.T.P.-V. All authors read and agreed to the published version of the manuscript.

Funding: This study was partly sponsored by a research grant from the Programa de Fomento a la Investigación of Universidad Juarez Autonoma de Tabasco through the project "Eficiencia energética madre/cría en ovinos de pelo" [PFI: UJAT-DACA-2015-IA-02].

Acknowledgments: The first author is grateful for the research grant provided by the National Council of Science and Technology of Mexico (CONACYT) for his postgraduate studies at the Universidad Juárez Autónoma de Tabasco, México. We would like to thank Jorge Quintal Franco and Martha Cecilia Ferraez Evia for use of the animal facilities in the "Rancho San Francisco".

Conflicts of Interest: The authors declare no conflict of interest. 


\section{References}

1. Kholif, A.E.; Gouda, G.A.; Galyean, M.L.; Anele, U.Y.; Morsy, T.A. Extract of Moringa oleifera leaves increases milk production and enhances milk fatty acid profile of Nubian goats. Agrofor. Sys. 2019, 93, 1877-1886. [CrossRef]

2. Dong, L.; Zhang, T.; Diao, Q. Effect of Dietary Supplementation of Moringa Oleifera on the Production Performance and Fecal Methanogenic Community of Lactating Dairy Cows. Animals 2019, 9, 262. [CrossRef] [PubMed]

3. Hao, X.; Wang, P.; Ren, Y.; Liu, G.; Zhang, J.; Leury, B.; Zhang, C. Effects of Astragalus membranaceus roots supplementation on growth performance, serum antioxidant and immune response in finishing lambs. Asian-Australas. J. Anim. 2020, 33, 965-972. [CrossRef] [PubMed]

4. Correddu, F.; Lunesu, M.F.; Buffa, G.; Atzori, A.S.; Nudda, A.; Battacone, G.; Pulina, G. Can Agro-Industrial By-Products Rich in Polyphenols be Advantageously Used in the Feeding and Nutrition of Dairy Small Ruminants? Animals 2020, 10, 131. [CrossRef] [PubMed]

5. El-Kady, R.I.; Kandil, A.M.; Boraie, M.A. Effect of feeding natural AND/OR commercial bio-Additives on the productive performance of lactating ewes. J. Agric. Sci. 2004, 29, 5567-5583.

6. Parraguez, V.H.; Sales, F.; Peralta, O.A.; Narbona, E.; Lira, R.; De los Reyes, M.; González-Bulnes, A. Supplementation of Underfed Twin-Bearing Ewes with Herbal Vitamins C and E: Impacts on Birth Weight, Postnatal Growth, and Pre-Weaning Survival of the Lambs. Animals 2020, 10, 652. [CrossRef] [PubMed]

7. Santos, S.; Falbo, M.; Sandini, I.; Ishiy, L.; Deliberalli, A.; Posso, L. Ryegrass pasture supplementation strategies for lactating ewe performance. Turk. J. Vet. Anim. Sci. 2017, 41, 787-792. [CrossRef]

8. Abdelmalek, Y.B.; Essid, I.; Smeti, S.; Atti, N. The antioxidant and antimicrobial effect of Rosmarinus Officinalis L. distillation residues' intake on cooked sausages from ewes fed linseed. Small Rumin. Res. 2018, 168, 87-93. [CrossRef]

9. Seidavi, A.; Tavakoli, M.; Rasouli, B.; Corazzin, M.; Salem, A.Z.M. Application of some trees/shrubs in ruminant feeding: A review. Agrofor. Syst. 2019,1-12. [CrossRef]

10. Babiker, E.E.; Juhaimi, F.A.L.; Ghafoor, K.; Abdoun, K.A. Comparative study on feeding value of Moringa leaves as a partial replacement for alfalfa hay in ewes and goats. Livest. Sci. 2017, 195, 21-26. [CrossRef]

11. Jenko, C.; Bonato, P.; Fabre, R.; Perlo, F.; Tisocco, O.; Teira, G. Adición de taninos a dietas de rumiantes y su efecto sobre la calidad y rendimiento de la carne. Cienc. Docencia Tecnol. 2018, 29, 224-241. [CrossRef]

12. Pollini, L.; Tringaniello, C.; Ianni, F.; Blasi, F.; Manes, J.; Cossignani, L. Impact of Ultrasound Extraction Parameters on the Antioxidant Properties of Moringa Oleifera Leaves. Antioxidants 2020, 9, 277. [CrossRef]

13. Babiker, E.E.; AL Juhaimi, F.; Ghafoor, K.; Mohamed, H.E.; Abdoun, K.A. Effect of partial replacement of alfalfa hay with Moringa species leaves on milk yield and composition of Najdi ewes. Trop. Anim. Health Prod. 2016, 48, 1427-1433. [CrossRef] [PubMed]

14. Kekana, T.W.; Marume, U.; Muya, C.M.; Nherera-Chokuda, F.V. Lactation performance and blood metabolites in lactating dairy cows micro-supplemented with Moringa oleifera leaf meal. S. Afr. J. Anim. Sci. 2019, 49, 709-716. [CrossRef]

15. Makkar, H.P.S.; Becker, K. Nutrients and anti- quality factors in different morphological parts of the Moringa oleifera tree. J. Agric. Sci. 1997, 128, 311-332. [CrossRef]

16. Foidl, N.; Makkar, H.P.S.; Berker., K. The potential of Moringa oleifera for agricultural and industrial uses. In The Miracle Tree: The Multiple Attributes of Moringa, 2nd ed.; Fuglie, L.J., Ed.; CTA/CWS: Dakar, Senegal, 2001; pp. $45-76$.

17. Mouchili, M.; Vargas-Bello-Pérez, E.; Tendonkeng, F.; Miégoué, E.; Wauffo, D.F.; Watsop, H.M.; Tedonkeng, E.P. Effects of different poultry manure fertilization levels and cutting times on Moringa oleifera production. Agric. Nat. Resour. 2019, 46, 310-318. [CrossRef]

18. Kholif, A.E.; Gouda, G.A.; Morsy, T.A.; Salem, A.Z.M.; Lopez, S.; Kholif, A.M. Moringa oleifera leaf meal as a protein source in lactating goat's diets: Feed intake, digestibility, ruminal fermentation, milk yield and composition, and its fatty acids profile. Small Rumin. Res. 2015, 129, 129-137. [CrossRef]

19. Kholif, A.E.; Gouda, G.A.; Olafadehan, O.A.; Abdo, M.M. Effects of replacement of Moringa oleifera for berseem clover in the diets of Nubian goats on feed utilization, and milk yield, composition and fatty acid profile. Animal 2018, 12, 964-972. [CrossRef] 
20. Moyo, B.; Oyedemi, S.; Masika, P.J.; Muchenje, V. Polyphenolic content and antioxidant properties of Moringa oleifera leaf extracts and enzymatic activity of liver from goats supplemented with Moringa oleifera leaves/sunflower seed cake. Meat Sci. 2012, 91, 441-447. [CrossRef]

21. INAFED (Instituto Nacional para el Federalismo y el Desarrollo Municipal). Available online: http: //www.inafed.gob.mx/work/enciclopedia/EMM31yucatan/municipios/31027a.html. (accessed on 3 January 2020).

22. INEGI (Instituto Nacional de Estadística y Geografía). Available online: https://www.inegi.org.mx/app/ cuadroentidad/AnuarioGeografico/Yuc/2018\#mapa_m_climas. (accessed on 3 January 2020).

23. Russel, A.J.F.; Doney, J.M.; Gunn, R.G. Subjective assessment of body fat in live sheep. J. Agric. Sci. 1969, 72 , 451-454. [CrossRef]

24. Correddu, F.; Gaspa, G.; Pulina, G.; Nudda, A. Grape seed and linseed, alone and in combination, enhance unsaturated fatty acids in the milk of Sarda dairy sheep. J. Dairy Sci. 2016, 99, 1725-1735. [CrossRef]

25. AFRC. Technical Committee on responses to nutrients. In Energy and Protein Requirements of Ruminants; CAB International: Wallingford, UK, 1993.

26. Chay-Canul, A.J.; Aguilar-Urquizo, E.; Parra-Bracamonte, G.M.; Piñeiro-Vazquez, Á.T.; Sanginés-García, J.R.; Magaña-Monforte, J.G.; García-Herrera, R.A.; López-Villalobos, N. Ewe and lamb pre-weaning performance of Pelibuey and Katahdin hair sheep breeds under humid tropical conditions. Ital. J. Anim. Sci. 2019, 18, 850-857. [CrossRef]

27. Tsiplakou, E.; Mavrommatis, A.; Kalogeropoulos, T.; Chatzikonstantinou, M.; Koutsouli, P.; Sotirakoglou, K.; Labrou, N.; Zervas, G. The effect of dietary supplementation with rumen-protected methionine alone or in combination with rumen-protected choline and betaine on sheep milk and antioxidant capacity. J. Anim. Physiol. Anim. Nutr. 2017, 101, 1004-1013. [CrossRef]

28. Bocquier, F.; Barillet, F.; Guillouet, G.; Jacquin, M. Prévision de l'énergie du lait de brebis à partir de différents résultats d'analyses: Proposition de lait standard pour les brebis laitières. Ann. Zootech. 1993, 42, 57-66. [CrossRef]

29. Ncube, B.; Ngunge, V.N.P.; Finnie, J.F.; Van Staden, J.A. Comparative study of the antimicrobial and phytochemical properties between outdoor grown and micropropagated Tulbaghia violacea Harv. plants. J. Ethnopharmacol. 2011, 134, 775-780. [CrossRef]

30. Selcuk, N.; Erkan, M. The effects of 1-MCP treatment on fruit quality of medlar fruit (Mespilus germanica L. cv. Istanbul) during long term storage in the palliflex storage system. Postharvest Biol. Technol. 2015, 100, 81-90. [CrossRef]

31. Çam, M.; Hişıl, Y. Pressurised water extraction of polyphenols from pomegranate peels. Food Chem. 2010, 123, 878-885. [CrossRef]

32. Moo-Huchin, V.M.; Moo-Huchin, M.I.; Estrada-León, R.J.; Cuevas-Glory, L.; Estrada-Mota, I.A.; Ortiz-Vázquez, E.; Sauri-Duch, E. Antioxidant compounds, antioxidant activity and phenolic content in peel from three tropical fruits from Yucatan, Mexico. Food Chem. 2015, 166, 17-22. [CrossRef]

33. SAS Institute Inc. SAS/STAT. Software, Ver. 9.00 edSAS Institute Inc.: Cary, NC, USA, 2002.

34. Vongsak, B.; Sithisarn, P.; Mangmool, S.; Thongpraditchote, S.; Wongkrajang, Y.; Gritsanapan, W. Maximizing total phenolics, total flavonoids contents and antioxidant activity of Moringa oleifera leaf extract by the appropriate extraction method. Ind. Crops Prod. 2013, 44, 566-571. [CrossRef]

35. Saleem, A.; Saleem, M.; Akhtar, M.F. Antioxidant, anti-inflammatory and antiarthritic potential of Moringa oleifera Lam: An ethnomedicinal plant of Moringaceae family. S. Afr. J. 2020, 128, 246-256. [CrossRef]

36. Du Toit, E.S.; Sithole, J.; Vorster, J. Leaf harvesting severity affects total phenolic and tannin content of fresh and dry leaves of Moringa oleifera Lam. trees growing in Gauteng, South Africa. S. Afr. J. Bot. 2019, in press. [CrossRef]

37. Lima, T.R.F.; Gallo, S.B.; Rosa, A.F.; Brochado, T.; Bezerra, H.V.A.; Putrino, S.M.; Leme, P.R. Effect of Macleaya cordata and Magnolia officinalis plant extracts on oxidative stress control in lambs fed a high-concentrate diet. Asian-Austral. J. Anim. 2020, 33, 913-920. [CrossRef] [PubMed]

38. Li, X.Z.; Park, B.K.; Yan, C.G.; Choi, J.G.; Ahn, J.S.; Shin, J.S. Effect of alcohol fermented feed on lactating performance, blood metabolites, milk fatty acid profile and cholesterol content in Holstein lactating cows. Asian-Austral. J. Anim. 2012, 25, 1546. [CrossRef] [PubMed] 
39. Daniel, J.L.P.; Amaral, R.C.; Neto, A.S.; Cabezas-Garcia, E.H.; Bispo, A.W.; Zopollatto, M.; Nussio, L.G. Performance of dairy cows fed high levels of acetic acid or ethanol. J. Dairy Sci. 2013, 96, 398-406. [CrossRef] [PubMed]

40. McGrath, J.; Duval, S.M.; Tamassia, L.F.M.; Kindermann, M.; Stemmler, R.T.; de Gouvea, V.N.; Acedo, T.S.; Immig, I.; Williams, S.N.; Celi, P. Nutritional strategies in ruminants: A lifetime approach. Res. Vet. Sci. 2018, 116, 28-39. [CrossRef] [PubMed]

41. Adegun, M.K.; Aye, P.A. Growth performance and economic analysis of West African Dwarf Rams fed Moringa oleifera and cotton seed cake as protein supplements to Panicum maximum. Am. J. Food. Nutr. 2013, 3, 58-63. [CrossRef]

42. Guzmán, J.L.; Perez-Ecija, A.; Zarazaga, L.A.; Martín-García, A.I.; Horcada, A.; Delgado-Pertíñez, M. Using dried orange pulp in the diet of dairy goats: Effects on milk yield and composition and blood parameters of dams and growth performance and carcass quality of kids. Animal 2020, 1-9. [CrossRef]

43. Titi, H.H.; Al-Fataftah, A.R. Effect of supplementation with vegetable oil on performance of lactating Awassi ewes, growth of their lambs and on fatty acid profile of milk and blood of lambs. Arch. Anim. Breed. 2013, 56, 467-479. [CrossRef]

44. Gallardo, B.; Manca, M.G.; Mantecón, A.R.; Nudda, A.; Manso, T. Effects of linseed oil and natural or synthetic vitamin E supplementation in lactating ewes' diets on meat fatty acid profile and lipid oxidation from their milk fed lambs. Meat Sci. 2015, 102, 79-89. [CrossRef]

45. Hong, H.; Lee, J.H.; Kim, S.K. Phytochemicals and antioxidant capacity of some tropical edible plants. Asian-Austral. J. Anim. 2018, 31, 1677. [CrossRef]

(C) 2020 by the authors. Licensee MDPI, Basel, Switzerland. This article is an open access article distributed under the terms and conditions of the Creative Commons Attribution (CC BY) license (http://creativecommons.org/licenses/by/4.0/). 